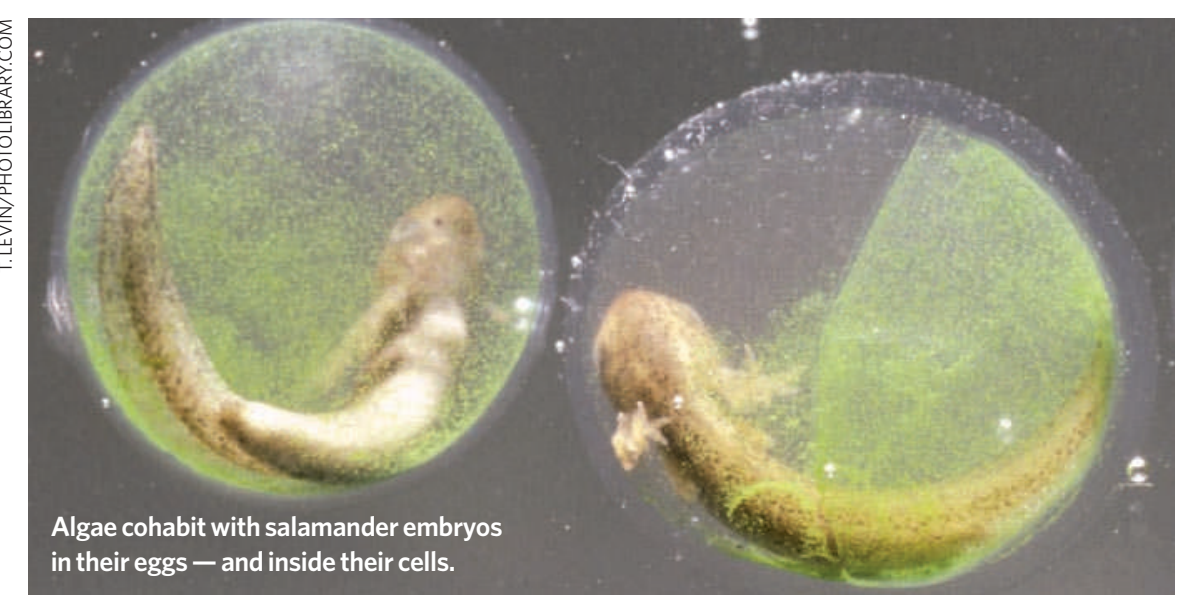

\title{
Salamander's egg surprise
}

\section{PUNTA DEL ESTE, URUGUAY}

Scientists have stumbled across the first example of a photosynthetic organism living inside a vertebrate's cells. The discovery is a surprise because the adaptive immune systems of vertebrates generally destroy foreign biological material. In this case, however, a symbiotic alga seems to be surviving unchallenged - and might be giving its host a solar-powered metabolic boost.

The embryos of the spotted salamander (Ambystoma maculatum) have long been known to enjoy a mutualistic relationship with the single-celled alga Oophila amblystomatis. The salamanders' viridescent eggs are coloured by algae living in the jelly-like material that surrounds the embryo. The embryos produce nitrogen-rich waste that is useful to the algae, which, in turn, supply the developing embryos with extra oxygen. The algae clearly benefit their salamander hosts: Lynda Goff, a molecular marine biologist at the University of California, Santa Cruz, showed 30 years ago that salamander embryos lacking algae in their surrounding jelly are slower to hatch.

Ryan Kerney of Dalhousie University in Halifax, Nova Scotia, Canada, has now found that these algae also live inside the embryo's cells. Such a close coexistence with a photosynthetic organism has previously been found only in invertebrates, such as corals. Kerney took long-exposure fluorescent images of pre-hatchling salamander embryos, and saw scattered dots in the unstained tissue - an indicator that it might contain chlorophyll. Transmission electron microscopy (TEM) images showed mitochondria in the salamander cells clustering close to the algae. Reporting the discovery on 28 July at the Ninth International Congress of Vertebrate Morphology in Punta del Este, Kerney suggested that the mitochondria might be taking advantage of both oxygen and carbohydrate generated by the alga's photosynthesis.

So when do the algae enter the embryos' cells? A time-lapse video made by Roger Hangarter at Indiana University in Bloomington, and presented by Kerney at the meeting, reveals a fluorescent green flash - an algal bloom - next to each embryo just as its nervous system begins to form. Most research on spotted salamander embryos has focused on earlier periods of development, which might explain why algae have not been seen inside the cells before.

One of Kerney's most curious discoveries suggests that the algae may be a maternal gift. He has found the same algae in the oviducts of adult female spotted salamanders, where the embryo-encompassing jelly sacs first form.

David Wake, an emeritus professor at the University of California, Berkeley, who watched Kerney's presentation, wonders whether algae could be getting into the reproductive cells. This would "really challenge the dogma" that vertebrates' immune systems ban such close relationships, he says. Both Wake and David Buckley, who studies salamander development at the National Museum of Natural Sciences in Madrid, agree that the work might tell us more about how vertebrate cells learn to identify intruders.

"It makes me wonder if other species of salamander that have known symbiotic relationships with algae also harbour algae inside their cells," adds Daniel Buchholz, a developmental biologist at the University of Cincinnati in Ohio. "I think that if people start looking we may see many more examples." Anna Petherick

For a longer version of this story, see http://go.nature.com/L2DrRP
SEWER STUDIES BASED ON LEAKY SCIENCE Sampling techniques could skew results. go.nature.com/gU9UV7

\section{'Tough' chief to defend MRC}

Britain's biomedical establishment has given an enthusiastic welcome to the incoming chief executive of the Medical Research Council (MRC).

John Savill was named last week as the man who will steer the agency through a round of public-spending cuts expected this autumn. In 2008-09, the governmentfunded agency spent $\mathfrak{E 7 0 4 . 2}$ million (US\$1.1 billion) on research, making it one of Europe's largest national supporters of biomedical research. But all of Britain's research councils recently drew up strategies to deal with cuts of up to $20 \%$ over four years (see Nature 466, 420-421; 2010).

"I find it hard to think of anybody else who is better able to defend the MRC", says Keith Peters, former president of learned society the Academy of Medical Sciences.

Savill, who is currently head of the College of Medicine and Veterinary Medicine at the University of Edinburgh, $\mathrm{UK}$, is also chief scientific adviser for health to the Scottish government. He will replace Leszek Borysiewicz, who is leaving the MRC to become vice-chancellor at the University of Cambridge, UK. Borysiewicz's departure, one year before his four-year term was due to expire, had prompted concerns that a power vacuum at the top of the agency might allow the government's Department of Health to steer it away from basic science and into more applied biomedical work (see Nature 462, 553; 2009). The appointment may assuage those concerns - colleagues say that Savill commands the respect of basic researchers and of clinicians, and knows the importance of both. "That is essential to secure the future of the MRC," says Colin Blakemore, a neuroscientist at the University of Oxford, UK, and Borysiewicz's predecessor at the MRC.

Savill trained as a medical doctor and was formerly head of Edinburgh's MRC Centre for Inflammation Research. "John is very experienced at working at the clinicalbasic science interface," says Kay Davies, honorary director of the MRC Functional Genomics Unit and head of the Department of Physiology, Anatomy and Genetics at the University of Oxford. "He is tough and dedicated to the scientific enterprise."

Savill, who was not available for interview, will start at the MRC on 1 October.

Daniel Cressey 